6,000 flies to a quart measure (South African J. Sci., 29,495 ; 1932). The year's total catch was much more than 7 millions, and that in spite of the fact that only for the last four months of the period had the traps approached their full number of just over one thousand.

It is clear that the fly population can be enormously reduced by trapping flies in their habitat amongst game animals; and the author suggests as a sound method of control, first, the creation of special game reserves in fly areas, so that the flies may be concentrated in definite localities in association with the game; second, the removal of most game animals in the territory surrounding the reserve, so that the flies may be isolated as well as concentrated; and third, the trapping of the flies in the concentrated reserve.

\section{Luminescence in Nature}

Now that darkness falls earlier and the plankton population of the shallow waters of the sea is still at a high level, opportunities increase for observing luminescence from the shore, due to the presence of Noctiluca or ctenophores or many other common forms. At the opening session of the American Philosophical Society's meeting at Philadelphia on April 15, 1932, Prof. E. Newton Harvey suggested that luminescence had been evolved from one of the biochemical reactions underlying ordinary respiration. Between luminescence, most familiar in the light of fireflies or the glow of bacteria, due to the reaction of luciferin and oxygen through the intermediary of the enzyme luciferase, and the hydrogen acceptor mechanism involved in the oxidation of food substances, he found a close analogy. But in the latter case carbon dioxide is set free, whereas in the former no carbon dioxide is released and the oxidised luciferin quickly loses its oxygen and is once more in a condition to react. Most luminescence is intermittent and is generally caused by some stimulus (for example, the breaking of waves, the stroke of an oar, the disturbance caused by the movement of a boat) and under natural conditions it may have protective value, may serve as a signal between members of a species, or in the darkness of the deep sea may illumine the depths, but these are unproved guesses. But what purpose the continuous, non-stimulated glow of bacteria may serve, not even the credulous naturalist has ventured to guess.

\section{Stubble Cultivation}

An early harvest gives a great opportunity to attack the weed population, already weakened by the shading action of the straw erop. Unfortunately, on heavy land the tearing up of hard-baked stubble has been no easy matter with the farmers' own implements, although hired steam traction sets have long been used to fulfil this need. With modern tractors and implements of sturdy construction, it is possible to make sufficient tilth on the surfaces of the stubbles to germinate weed seeds at the first shower, and at the same time the established weeds are uprooted and checked. One of the great advantages of the tractor is that it provides the power to carry out these operations thoroughly and rapidly, making the best use of the restricted time available. If dry conditions continue, the runners of grassy weeds may be combed out and burnt. The growth of seedling weeds is allowed to proceed for some time, when the green stuff is ploughed in and has a certain manurial value. An alternative to the above procedure is to plough up the stubbles at once without attempting to get rid of any viable weed seeds. This has the advantage that heavy land is at any rate safe for the winter, whereas if merely broken there is the risk that it may lie too wet for ploughing for long periods late in the year.

\section{Societies and Academies \\ DUBLIN}

Royal Irish Academy, June 26. F. D. Greeves : An investigation on the penetrating radiation from potassium. Measurements of the absorption of the $\gamma$-radiation from potassium chloride by use of a Geiger tube counter. The value obtained by Mühlhoff was confirmed with a different geometrical arrangement. The background of cosmic and local radiation was found to vary with weather conditions, being less intense during rain. H. O'Neicl Hencken and H. L. Movius : The cemetery cairn at Knockast, Co. Westmeath. In August and September 1932, the first Harvard Archæological Mission in Ireland, under the direction of Dr. H. O'Neill Hencken, assistant curator of European archæology in the Peabody Museum of Harvard University, excavated at Coolatore, Co. Westmeath, a large cemetery cairn of the Bronze Age. This contained in all 44 burials of which 4 were skeletons and the remainder cremations. Unlike most such grave-mounds, this contained no central burial with 'secondary interments' grouped about it, but an unprecedented number of graves scattered through it. From the pottery, bronze knives, etc., found with the burials, it was evident that they covered a considerable part of the Bronze Age from about 1500 B.c. to somewhat after 1000 B.c. The human remains have been studied by Mr. H. L. Movius of Harvard. He has found that the skeletons conform on the whole to the general type of Irish Bronze Age skeletons, but believes that the cremating people probably belonged to a different physical type. J. Doyxe and W. T. SAxton : Contributions to the life-history of Fitzroya. Fitzroya is an interesting link between the cupressinean and callitrinean conifers. It possesses an apical archegonial complex with a pollen tube directed to the top of the prothallus. The tube grows early and invaginates the prothallus deeply while the latter is still vacuolate. The pro-embryo is variable and the variations are discussed. They seem to be derivatives of two types of early pro-embryo, a four-celled pro-embryo completely filling the archegonium and one with four cells occupying a considerable part of the archegonium with a fifth free nucleus in the upper part. The mature pro-embryo commonly fills the archegonium and is fully septate. J. J. NoLAN and P. J. NolaN : Further observations on atmospheric ionisation at Glencree. In a survey of more than four years' observations, it is shown that the control exercised by the condensation nuclei on the equilibrium of ionisation is very weak. Certain diumal variations in the ionisation are found and the question of a diurnal variation in the rate of ion production is examined. R. W. DitchburN and Miss C. J. PowerSterle : Notes on resolving power (2). The resolving power with a microphotometer. The paper describes experiments on the resolving power of an optical system (for example, telescope or spectrograph) when photographic methods are used. The 
effect on the resolution produced by exposure, time and other factors is examined. The resolving power of lines of different intensity ratio is investigated. An increase of resolution is obtained by stopping out the central portion of the aperture. A new 'characteristic' is suggested for use in connexion with the deflection microphotometer. R. W. DitchBURN : Notes on resolving power (3). The resolving power of the method of focal isolation. The paper discusses the resolving power and the geometrical opties of the method of focal isolation (see R. W. Wood: "Physical Optics". Second edition, p. 414). The relation of this method to the Christiansen filter is considered.

\section{PARIS}

Academy of Sciences, July 17 (C.R., 197, 205-284). A. Calmetre, A. Saenz and L. Costur: The effects of cobra poison on cancerous grafts and on spontaneous cancer (adeno-carcinoma) of mice. Cobra poison has an undoubted curative effect on spontaneous or grafted adeno-carcinoma in mice. S. WINOGRADSKY : The disengagement of ammonia by the nodules of the roots of the Leguminosæ. Young nodules borne by plants in full growth give off measurable quantities of ammonia. SERge Bernstein : Remark on a note by R. Salem. Auguste Lumière: The method of heterogeneous test statistios. A new method of investigating statistics in cases unsuitable for the application of mathematical methods. P. RACHEVSKI : The infinitesimal interpretation of the system of dual vectors. G. B. Gourewitck : An algebraical equation in polyvectors. SILvio MrNeTTr: The geometry of the holospace of holomorph functions in a given domain and its relations with the theory of ordinary differential equations. LICHINE : Controls. A system of controlling motors without mechanical contact. Max SERRuYs: Knocking and auto-ignition in internal combustion motors. Knocking and auto-ignition in internal combustion engines are separate phenomena. Thadés Peczalsiri: The cause and effect of the solution of salt in metal. Eugene Dupur and L. Hackspill: The law of thermal expansion of boron. The linear coefficient of expansion of boron between $20^{\circ} \mathrm{C}$. and $750^{\circ} \mathrm{C}$. is $8.3 \times 10^{-6}$ : the expansion is a linear function of the temperature and no anomalous point was found. D. Bodroux and R. RrvaulT : Some distant receptions of television broadcasts from London. Account of experiments on television reception at Poitiers. E. THELlIER : A magnetometer insensitive to the disturbed magnetic fields of large towns. Pierre Lambert and Jean Lecomte : Infra-red absorption spectra of organic compounds possessing two chromophores. MrLe. J. ClaviaR: The influence of the temperature on the chromatic sensibility of some photographic plates. The results depended largely on the make of the plate, but the sensibility in several cases was much increased (three to four times) by raising the temperature of the plate to $60^{\circ}-80^{\circ} \mathrm{C}$. MMr. Ireters Curie and F. Joliors: The complexity of the proton and the mass of the neutron. It is suggested that the proton may be considered as containing a neutron and a positive electron : the energy of combination is of the order of $5 \times 10^{6} \mathrm{ev}$. and the stability is consequently very high. T. GRAF : The magnetic spectrum of the $\beta$-rays emitted by $\mathrm{AcB}+\mathrm{C}+\mathrm{C}^{\prime}+\mathrm{C}^{\prime \prime}$. Henri Muller: The lowering of the ternary eutectic point ice - potassium nitrate - ammonium chloride. H. Hering : Heterogeneous equilibria in the system cadmium iodide, potassium iodide and water. Fr. HAHN : The determination of traces of bromine in the presence of a large excess of chlorine. The method, which is based on the production of eosin from fluorescin, can be used to determine quantities of bromine of the order $0 \cdot 1-2$ micrograms. JđLEs GúxRoN: The spontaneous evolution of aqueous solutions of stannic chloride. H. Delomente : Contribution to the study of ferrosilicons. A. Travers and Prerre Leduc: The evolution of the hydrated calcium aluminates. $\mathrm{H}$. Cotrin : Pentenylamine. Marcel Sommelet : The synthetical preparation of chlormethyl derivatives of phenols. J. DÉcombe : The condensation of formol, amines and phenols. Antonis Lanquine: The lengthening of the edge of the Jurassic massif of Thèmes and of its approaches in the neighbourhood of Rocbaron and Carnoules (Var). D. SchneEgans : The relations between the Flysch zone in the Embrunais and the sheet of the Briançonnais. $R$. GuIZoNNIER : The gradient of electric potential and atmospheric pressure. An important relation holds between the gradient of the electric potential and atmospheric pressure. This is shown by the parallelism of the curves exhibited by these elements as a function of the time. J. RIBEREAU-GAYON: The solubility of the copper compounds of anti-cryptogamic mixtures, Charlas PÉrez: Some sexual differences in the crab Pachygrapsus marmoratus. C. Matuis and L. Berland: A domestic Afriean spider, Plexippus paykulli, a natural enemy of Stegomyia, living in houses. This spider hunts and kills mosquitoes : it is inoffensive to man and should be cultivated as a useful auxiliary for the destruction of the female Stegomyia, the active agent in the propagation of yellow fever. B. TrOUvELOT, LACOTTE, DUSSY and THÉNARD: Observations on the trophic affinities existing between the larvæ of Leptinotarsa decemlineata and plants of the Solanaceæ family. W. S. Rerch and A. F. Damansky : Contribution to the study of starch. New esters obtained by cinnamylation. The method of acetylation of starch described in an earlier paper has been applied to the cinnamylation of starch. Natural starch gives a dicinnamate, amylose a tricinnamate. L. VeLLUz and P. SAULEAU : The biochemical synthesis of the fatty esters of some cyclohexanols. MME. ANDrÉe ROCHE : Nitrogen loss and protein starvation. The experiments described agree with the hypothesis of the partial disintegration of a muscle protein in the case where the need of nitrogen is not met by the food. Pierre Rosenthal: Regenerescence cure by interhuman serotherapy. A. MougEot and V. Aubertot : Intratissue oxidations and thermal carbonic acid baths.

\section{Geneva}

Society of Physics and Natural History, June 15. R. Galopin: Outline of the study of the opaque minerals of the Azégour deposit (Morocco). The author studies the metallic minerals of the Azégour deposit by reflected light. With the view of finding out the most promising direction for his work, he has examined some specimens taken at various localities and has found, in addition to minerals already known in this deposit, a certain number of others. These preliminary researches show that the mineralisation is more varied and complex than had hitherto been supposed. G. Gutzert and R. DUCKert : The aminoformate of copper and zinc. The authors have prepared these two salts and have studied their 
electrical conductivities, from which they have been able to give constitutional formulæ to these salts. G. Gutzerr : Remark on a relation between the apparent volumes of the atoms and the centres of co-ordination of internal complex compounds.

\section{SYDNEY}

Royal Society of New South Wales, May 3. W. R. Browne : Post-Palæozoic igneous activity in New South Wales (Presidential Address). The Mesozoic era was one of comparative freedom from volcanic activity, but Triassic volcanic ash and Jurassic basalts are known. About 11,000 square miles are covered with Tertiary basalts, etc., and the original area was probably much greater. Two groups of eruptions are recognised: (I) an older, of basic flows and sills, followed by alkaline intermediate lavas and intrusions; (2) a newer, of basic flows and intrusions, with a few acid flows, followed by a series of narrow basic dykes and sills. The basic lavas comprise calcic and plateau-basalts, with alkaline basic and ultrabasic types. The older basic intrusives are teschenitic, the newer theralitic. Dolerite intrusions may represent portions of the calcic basalt magma. The eruptions were connected with vertical crust-movements and the whole series is comagmatic with the Tertiary rocks in Queensland, Victoria and Tasmania.

\section{Forthcoming Events}

British Association for the Advancement of Science (Leicester Meetrng).

Tuesday, September 5

At 8 p.m.-.Sir Henry Fowler: "Transport for a Century" (Public Lecture at Fdward Wood Hall).

\section{Wednesday, September 6}

At 8.30 p.m.-Sir Frederick Gowland Hopkins : "Some Chemical Aspects of Life" (Presidential Address at De Montfort Hall).

\section{Thursday, September 7}

At 10 a.m.-Prof. R. Robinson: "Natural Colouring Matters and their Analogues" (Presidential Address to Section B).

Prof. W. G. Fearnsides : "A Correlation of Structures in the Coalfields of the Midland Province" (Presidential Address to Section C).

Dr. J. Gray: "The Mechanical View of Life" (Presidential Address to Section D)

Mr. R. W. Allen : "Some Experiences in Mechanical Engineering" (Presidential Address to Section G).

Major the Hon. Richard Coke: "A System of Forestry for the British Isles (Chairman's Address to Depart. ment of Forestry ( $\left.K^{*}\right)$, Section K).

Dr. A. Lauder: "Chemistry and Agriculture" (Presidential Address to Section M).

At 11.30 a.m.--Prof. J. H. Jones : "The Gold Standard" (Presidential Address to Section F).

The Right Hon. Lord Raglan: "What is Tradition?" (Presidential Address to Section $\mathrm{H}$ ).

At 2.0 p.m.--Dr. R. E. Mortimer Wheeler : "Centralisation and Control of Research in its Relation to Learned Societies" (Presidential Address to the Conference of Delegates of Corresponding Societies).

\section{Friday, September 8}

At 10 a.m.-Sir Gilbert Walker: "Seasonal Weather and Its Prediction" (Presidential Address to Section A). Prof. F. Aveling: "The Status of Psyehology as an Empirical Science" (Presidential Address to Section J).
At noon.-Prof. E. D. Adrian: "The Activity of Nerve Cells" (Presidential Address to Section I).

At 8.15 p.m.-Sir Josiah Stamp: "Must Science ruin Economic Progress ?" (Evening Discourse at Wyggeston Boys' School Hall).

\section{Saturday, September 9}

At 8.0 p.m.--Prof. Julian S. Huxley : "Ants and Men" (Public Lecture at Edward Wood Hall).

\section{Monday, September 11}

At 10 a.m.-The Right Hon. Lord Meston: "Geography as Mental Equipment" (Presidential Address to Section $\mathrm{E})$.

Prof. F. E. Lloyd : "The Types of Entrance Mechanisms of the Traps of Utricularia (including Polypompholyx) (Presidential Address to Section K, at Vaughan College) At 5.30 p.m.- Sir Richard Gregory, Prof. W. J. Pugh, Prof. W. B. Brierley, Dr. Allan Ferguson, Prof. J. L. Myres, Sir Josiah Stamp. Symposium on "Cultural Value of Science in Adult Education" (Open to the Public).

At 8.15 p.m.-Prof. J. F. Thorpe: "The Work of the Safety in Mines Research Board" (Evening Discourse at Lancaster Hall).

Tuesday, September 12

At 10 a.m.-Mr. J. L. Holland: "The Development of the National System of Education" (Presidential Address to Section L).

\section{Official Publications Received}

\section{GREAT BRITAIN AND IRRLAND}

Mines Department. Eleventh Annual Report of the Safety in Mines Research Board, including a Report of Matters dealt with by the Health Advisory Committee, 1932. Pp. $112+15$ plates. (London : H.M. Stationery Office.) 2s. net.

Air Ministry: Aeronautical Research Committee: Reports and Memoranda. No. 1509 (Strut. 113): Stability of Static Equilibrium of Elastic and Aerodynamic Actions on a Wing. By Dr. H. Roxbe Cox and A. G. Pugsley. Pp. $20+2$ plates. 18. net. No 151 (T.3286): Full Scale Experiments with Servo Rudders. By I. E. Serby. Pp. $8+12$ plates. 9d. net. No. 1526 : Abstract, Calculation of Stresses in Braced Frameworks. By R. V. Southwell. Pp. 1 $2 d$. net. (Iondon: H.M. Stationery Office.)

Proceedings of the Royal Society, Series A, Vol. 141, No. A844 August 1. Pp. 281-493. (London: Harrison and Sons, Ltd.) 12s. Proceedings of the Royal Society of Fdinburgh, Session 1932-1933. Vol. 53, Part 3, No 16. Studies on the Reproductive System in the Guinea-Pig - Variations in the CEstrous Cycle in the Virgin Animal after Parturition, and during Pregnancy. By Thomas Nicol. Pp. 220after Parturition, and during Pregnancy. By Thomas Nicol. Pp. 220 Norgate, Ltd.) 18. $6 d$.

\section{OTHER COUNTRIES}

U.S. Department of the Interior: Geological Survey. Bulletin 849-A : Progress of Surveys in the Anthracite Ride District, Alaska. By Ralph W. Richards and Gerald A. Waring. (Investigations in Alaska Railroad Belt, 1931.) Pp. ii $+27+2$ plates. (Washington, D.C. : Government Printing Office) 5 cents.

Geological Memoirs. Series A, No. 11: Fossil Man in China. The Geological Memoirs. Series A, No. 11 : Fossil Man in China. The of the Late Cenozoic in China. By Davidson Black, Teilhard de of the Late Cenozoic in China. By Davidson Black, Teilhard de Pp. $x+166+6$ plates. (Peiping: Geological Survey of China.)

Pp. $x+166+6$ plates. (Peiping: Geological suryey of China.) Vol. 8, No. 3, June 30. Pp. iii+109-163+53-79. (Tokyo: National Re , No. Sune 30 . Pp.

Seismotion ift Pp. 19-24 + plates 16-20. (Tokyo.) Koninklijk Magnetisch en Meteorologisch Observatorium te Batavia. Jaarverslag 1932. Pp. 15. Verhandelingen No. 24: Ratavia. Jaarverslag 1932. Pp. 15. Verhandelingen No. 24 Reor (By) Prof. Dr. J. Boerema. Deel (Vol.) 3: Kaarten van den Door By Prof. Dr. J. Boerema. Deel kol.) (Maps of the Mean Annual and Monthly Rainfall in Borneo.) 13 Maps of the Mean

Advisory Department of the Imperial College of Tropical Agriculture. Report on the Agricultural Department, St. Lucia, 1932. Pp. iv +39 Report on the Agricultural Department, St. Lute
(St. Lucia : Government Printing Office.) 6d.

\section{Editorial and Publishing Offices:} MACMILLAN \& CO., LTD.

ST. MARTIN'S STREET, LONDON, W.C.2

Telephone Number: WHITEHALL $883 \mathrm{I}$ Telegraphic Address: PHUSIS, LESQUARE, LONDON 